\title{
Characterization of platelet disorders using quantitative proteomics
}

Citation for published version (APA):

Solari, F. A. (2018). Characterization of platelet disorders using quantitative proteomics. [Doctoral Thesis, Maastricht University]. Uitgeverij BOXPress || Proefschriftmaken.nl. https://doi.org/10.26481/dis.20180626fs

Document status and date:

Published: 01/01/2018

DOI:

$10.26481 /$ dis.20180626fs

Document Version:

Publisher's PDF, also known as Version of record

\section{Please check the document version of this publication:}

- A submitted manuscript is the version of the article upon submission and before peer-review. There can be important differences between the submitted version and the official published version of record.

People interested in the research are advised to contact the author for the final version of the publication, or visit the DOI to the publisher's website.

- The final author version and the galley proof are versions of the publication after peer review.

- The final published version features the final layout of the paper including the volume, issue and page numbers.

Link to publication

\footnotetext{
General rights rights.

- You may freely distribute the URL identifying the publication in the public portal. please follow below link for the End User Agreement:

www.umlib.nl/taverne-license

Take down policy

If you believe that this document breaches copyright please contact us at:

repository@maastrichtuniversity.nl

providing details and we will investigate your claim.
}

Copyright and moral rights for the publications made accessible in the public portal are retained by the authors and/or other copyright owners and it is a condition of accessing publications that users recognise and abide by the legal requirements associated with these

- Users may download and print one copy of any publication from the public portal for the purpose of private study or research.

- You may not further distribute the material or use it for any profit-making activity or commercial gain

If the publication is distributed under the terms of Article $25 \mathrm{fa}$ of the Dutch Copyright Act, indicated by the "Taverne" license above, 


\section{Summary}

Blood platelets are key mediators of hemostasis, being responsible of the formation of a blood clot after vessel wall injury. Platelet dysfunction or a low platelet count may thus lead to an increased bleeding risk. On the other hand, unwanted platelet reactivity in an atherosclerotic blood vessel may result in cardiovascular disease, such as heart infarction or stroke. Since platelets lack nuclei, they have a limited capacity of protein translation, implying that their protein content is relatively stable. Accordingly, proteomics approaches can be regarded as valuable tools to study the composition and activation state of platelets in health and disease. Usage of modern mass-spectrometry based proteomics, as presented in this thesis, allows full characterization of the platelet proteome, phosphoproteome and N-terminone. This technology now has the potential to elucidate new molecular mechanisms and novel biomarkers of platelet activation, which may serve for future diagnostic and therapeutic approaches.

Chapter 1 of this thesis provides a general introduction of established platelet functions and mechanisms in hemostasis. In addition, this chapter underscores the importance of studying platelets from healthy and diseased subjects using proteomics approaches, to gain insight into normal and affected platelet activation mechanisms. In Chapter 2 a review is presented on important pitfalls in the performing and analysis of phosphoproteomics experiments. In this opinion article, major flaws and challenges of the technology are discussed, as well as strategies to address current problems in phosphoproteomics studies. In Chapter $\mathbf{3}$ an improved Charged based Fractional Diagonal Chromatography (ChaFRADIC) approach is developed. Tools are described on how to: (i) assess the reproducibility of $\mathrm{N}$-terminomics workflows using ITRAQ technology, (ii) evaluate the benefit of a multi-protease approach to increase the $\mathrm{N}$-terminome coverage, and (iii) investigate the possibility to scale down sample amounts for $\mathrm{N}$-terminomics experiments. For this work, Arabidopsis thaliana seedlings were divided into six aliquots, and per aliqout, the proteins were individually labeled with stable isotope iTRAQ reagents. After pooling, the sample was divided again into three parts, each of which was digested with different proteases. After ChaFRADIC, the enriched fractions containing N-terminal peptides were analyzed by LC-MS/MS. Altogether; we quantified 2,249 unique N-termini from 1,270 Arabidopsis proteins, in a way that sample amounts for $\mathrm{N}$-terminomics workflows could be down-scaled to become applicable for biomedical research. In addition, the data showed the advantage of a multiprotease digestion approach. We observed low overlap between the quantified N-terminal peptides among the 3 digestions, in that $82 \%$ of the $\mathrm{N}$-terminal peptides were quantified with just one protease. Given the low variation of the ITRAQ intensities in the three data sets, we 
concluded that the reproducibility of this $\mathrm{N}$-terminomics workflow was good. A relevant biological result was that our analysis could underscore the roles of known intracellular endoproteolytic pathways in plant cells, such as the $\mathrm{N}$-terminal methionine excision and the $\mathrm{N}$ end rule degradation pathways.

In Chapter 4, we performed a multipronged analysis of the proteome, phosphoproteome and Nterminome of platelets from control subjects and a Scott platelets in order to investigate mechanisms underlying the platelet procoagulant response. The Scott syndrome is a rare bleeding disorder, characterized by mutations in the ion channel/scramblase protein, anoctamin6. Platelets from Scott patients show impairments in $\mathrm{Ca}^{2+}$-dependent procoagulant phosphatidylserine exposure, protein cleavage and balloon formation (membrane blebbing). These impairments are seen, when Scott platelets are stimulated with strong, $\mathrm{Ca}^{2+}$-elevating agonists, such as convulxin/thrombin or ionomycin. Using an iTRAQ-based proteomics workflow, we found minor changes at the quantitative proteome level in 2,278 proteins, except for anoctamin- 6 and calpain-2 catalytic subunit which were down-regulated, and aquaporin-1 which was up-regulated in the patient's platelets. By parallel reaction monitoring analyses, we verified that anoctamin-6 was absent and aquaporin-1 was present in the syndromatic platelets. Additional phosphoproteomic analysis, using the same samples, resulted in 1,566 quantified phosphopeptides, which showed major changes in phosphorylation patterns between control and Scott platelets, after stimulation with convulxin/thrombin or ionomycin.

In Chapter 4, we also assessed the intracellular proteolytic activity of the $\mathrm{Ca}^{2+}$-dependent protease calpain in activated platelets. Firstly, calpain consensus motifs were defined using a separate proteomics workflow. Then, platelets from control subjects were stimulated in the presence or absence of a calpain or caspase inhibitor, and used for ChaFRADIC to enrich for newly formed N-terminal peptides. This resulted in a list of 180 calpain-regulated cleavage sites in platelets, while a distinct set of 23 cleavage sites appeared to be caspase-regulated. Subsequently, the convulxin/thrombin- or ionomycin-stimulated patient platelets were subjected to ChaFRADIC and neo-N-terminal peptide analysis, in order to assess the calpain substrates involved in the procoagulant response. This analysis indicated that multiple of the calpainregulated cleavage sites were down-regulated in the activated Scott platelets. Phenotypic analysis, using microfluidics and Western blotting, confirmed that the patient's platelets were deficient in procoagulant response and were reduced in calpain activity.

In Chapter 5, we compared altered platelet function with quantitative phosphoproteomics analysis for platelets from Albright hereditary osteodystrophy (AHO) patients, carrying a mutation in the GNAS complex gene locus for Gsa. Such patients have impairments in the 
inhibitory platelet signaling pathway, mediated by Gs $\alpha$, adenylate cyclase, cAMP and protein kinase A (PKA). Under certain conditions, this hence leads to platelet hyperactivity. In AHO platelets, we observed a reduced ability of Gsa-signaling prostaglandins (prostaglandin $E_{1}$ and iloprost) to inhibit platelet aggregation, secretion and thrombus formation. This was confirmed by proteomics analyses, in that AHO platelets, in comparison to platelets from controls, showed hypo-responsiveness of iloprost-induced protein phosphorylation. Thus, from the 3,457 quantified phosphopeptides, $62 \%$ appeared to be upregulated in control platelets, but relatively decreased in the patient's platelets. Several of the regulated phosphorylation sites are known PKA targets, such as vasodilator-stimulated phosphoprotein and phospholipase C- $\beta 3$, whilst 149 novel phosphorylation sites were elucidated.

In Chapter 6, we focussed on ADP-induced phosphorylation pathways in platelets from healthy subjects. The autacoid ADP, released from activated platelets, binds to the G-protein coupled receptors $\mathrm{P}_{2} \mathrm{Y}_{1}$ and $\mathrm{P} 2 \mathrm{Y}_{12}$, and triggers downstream signal cascades, leading to platelet aggregation. Drugs interfering with the $\mathrm{P}_{2} \mathrm{Y}_{12}$ receptors are frequently prescribed to patients suffering from cardiovascular disease. We applied a quantitative phosphoproteomics approach to study the temporal phosphorylation events induced by ADP alone or in combination with the platelet-inhibiting prostacyclin analog, iloprost. This resulted in temporal profiles of 4,797 phosphopeptides, of which 608 showed a significant regulation by ADP/iloprost. The regulatory sites were linked to mostly to proteins involved in platelet degranulation, cytoskeletal reorganization and pathways involving ubiquitin ligases or GTPase exchange factors/GTPaseactivating proteins. Overall, this resulted in a complete map of phosphorylation events induced by ADP alone or in combination with iloprost. Interestingly, certain phosphorylation sites were inversely regulated by ADP and iloprost, as confirmed by a developed assays using parallelreaction monitoring, suggesting that these sites may act as central nodes in platelet homeostasis. Chapter 8 presents a workflow to simultaneously analyzed cellular proteins, lipids and metabolites, named SImultaneous Metabolite, Protein and Lipid EXtraction procedure (SIMPLEX). The development of such a strategy allows the investigation of complex signaling networks that rely on protein-lipid and protein-metabolite interactions. In the SIMPLEX workflow, the separation of proteins, lipids and metabolites is done by differential extraction and centrifugation, to minimize contamination between these molecular classes. The method does not require higher amounts of starting material than any other proteomic measurements. As a proof-of-principle we conducted SIMPLEX using mesenchymal OP9 cells, in which we quantified 360 lipid species, 75 metabolites, 3327 proteins and 1846 phosphopeptides. We compared SIMPLEX to standard proteomics and metabolomics workflows, such as filter-aided sample 
preparation and methanol extraction, respectively. In both comparisons, a good percentage of recovery was achieved with SIMPLEX. In addition, we investigated the peroxisomal proliferatoractivated receptor- $\gamma$ signaling pathway, where changes at the proteome level appeared to correlate well with changes at the lipidome level, particularly with respect to triacylglycerol turnover. Overall, SIMPLEX showed to be a robust, sensitive and reproducible protocol to analyze cross-talk between different molecular classes in a cell, with promising possibilities for the future analysis of platelets. 